\title{
EXAMINING FACTORS INFLUENCING ARCHITECTURAL INTERVENTIONS ON SHOPHOUSE FAÇADE IN KOTA BHARU, KELANTAN
}

\author{
Yasmin Mohd Faudzi \\ Faculty of Architecture and Ekistics, \\ Universiti Malaysia Kelantan Beg Berkunci No. 01, 16300 Bachok, Kelantan. \\ (Email: yasmin,mf@umk.edu.my)
}

Received date: $17-07-2019$

Revised date: $31-07-2019$

Accepted date: 13-08-2019

Published date: 11-09-2019

To cite this document: Faudzi, Y. M. (2019). Examining Factors Influencing Architectural Interventions on Shophouse Façade in Kota Bahru, Kelantan. International Journal of Modern Trends in Social Sciences, 2(9), 11-20.

DOI: $10.35631 / \mathrm{IJMTSS} .29002$

\begin{abstract}
This article concerns the emergence of architectural interventions on heritage shophouse facades in the study zone of Kota Bharu, Kelantan. The intense urban development in Malaysia brought on by the needs and demands from society has had a significant impact on heritage shophouses. The objective of this paper is to classify factors that influenced the architecture interventions on shophouse facades in the study area. The emergence of architectural interventions on shophouse facades was influenced by the modernisation of the urban area as well as a lack of awareness from the shophouse owners. Moreover, the lack of legislation and poor enforcement of existing legislation by the local authority has triggered the demolition of shophouse facades. A face to face interview and observation method was applied to obtain the data. Several interview session with shophouses owners and the local authority was done to answer research objectives. Observations were carried out on four selected units of shophouse facades along Jalan Temenggung in the study area. The findings exposed that besides natural causes, architectural interventions were caused by poor awareness by the building owners and the local authority; urban growth; and financial constraints. The finding may be useful to many stakeholders such as the shophouse owners themselves, local authority as well as the heritage practitioner in order to sustain and conserve the heritage shophouse as part of the national treasure.
\end{abstract}

Keywords: Examining Factors Of Architectural Interventions, Shophouse Façade, Heritage Shophouse, Heritage Façade, Building Conservation, Urban Heritage, Urban Conservation, Heritage Conservation, Urban Growth, Historical City 


\section{Introduction}

Remarkable of past architectural style has been molded by significant architectural heritage property that stands as a prominent artifact. These heritage assets owned its physical and spiritual strength. Without a right control of urban growth and architecture interventions to uphold those qualities, heritage elements and property will deteriorate due to natural causes and other factors. Architecture heritage property has an intrinsic form and visual value of heritage urban pattern which should be wisely sustained and conserved. As appointed by

Mohga (2014), in order to implement heritage conservation by considering cultural context and qualified planning and design, local traditional and cultural values of communities for future generations shall be a great challenge for construction and design team to take responsibilities on that issues. The challenges of an abandonment of the inner city, urban growth pressure, scarce lawmaking as well as poor implementation affect the urban conservation nowadays (Ahmad, 2008). In addition, inappropriate design of new township, changes of urban lifestyle and poor awareness of society are also among the significant issues in sustaining the heritage value currently (Ahmad, 2008).

Architectural interventions on building façade have created a series of modified or different images and form on the urban setting and place ambiance. Building façade symbolize the value of building structure as well as a connection and transition between interior and exterior environment. The formation of new architectural interventions towards existing urban fabric shall be significant in creating and sustaining the originality and essence of heritage ambiance. The isolation state of heritage shophouses in the fast growing development in the study area has caused less appreciation of heritage value by locals and society. Rapid expansion and modernization has put the heritage shophouses in isolation state because of the emergence of new modern buildings in the surrounding study area. Also, poor characters of shophouse façade image has not been maintained and well emphasized by the local authority and owners. Deficiency of maintenance and preservation by the shop house owners has caused poor and inappropriate image of the heritage shop houses. The change of function also has distracted the environment as well as the ambiance of the heritage site. In addition, the aesthetic value of shophouse façade also has been ignored by changing the strait eclectic style façade to modern façade which undermined the continuity of heritage façade. The shophouse façade has been renovated to modern architecture style irrespective the existing strait eclectic architecture style. In addition, the demolition of historical asset of shophouse façade nowadays becomes a crucial issue in Kota Bharu, to allow new buildings development.

Observation of 74 units of shophouses along Jalan Temenggung (Figure 1) was conducted and analysed by capturing the image of the shophouse's façade by blocks. 


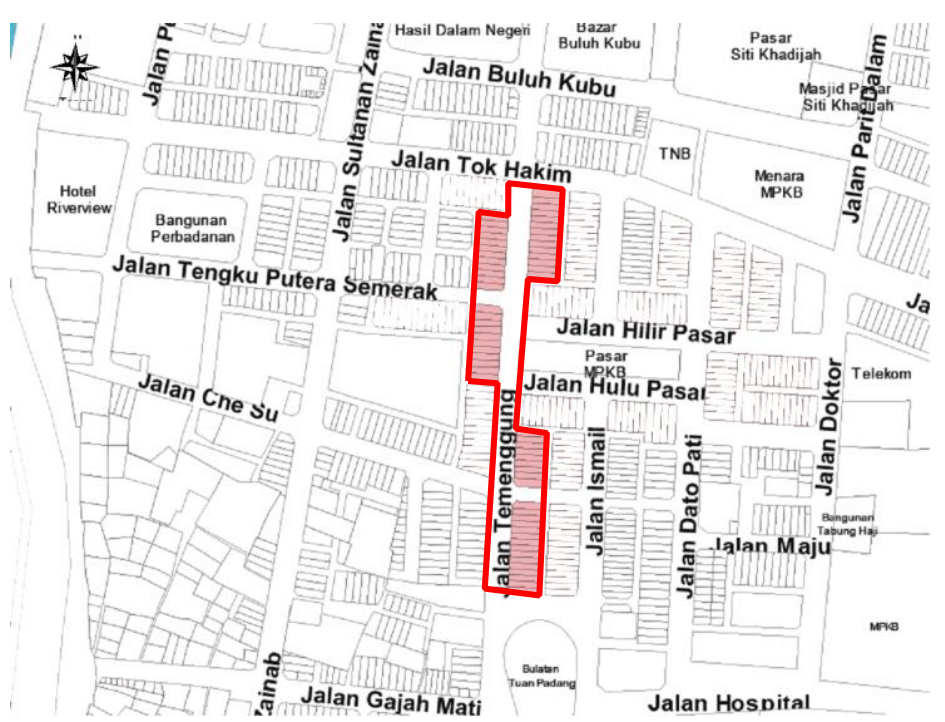

Figure 1: Study area of Jalan Temenggung

The current image of each unit will be compared to the image captured by Majlis Perbandaran Kota Bharu, AJM - PUDG in 2005. The change of façade elements between 2005 to 2014 were recorded. All unit of shophouse of Jalan Temenggung with Straits Eclectic architecture style will be observed and captured to justify degree of architectural interventions on façade elements by means of any changes or modification, alteration, renovation, repainted, and refurbishment from 2005 to 2014 as shown in Figure 2 and 3 below.

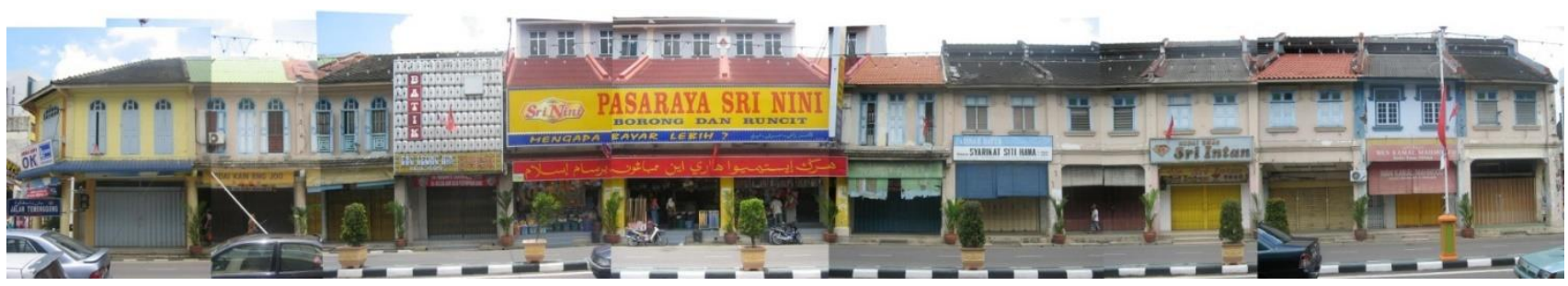

Figure 2: Shophouses along Jalan Temenggung in 2005 (MPKB, AJM - PUDG (2005)

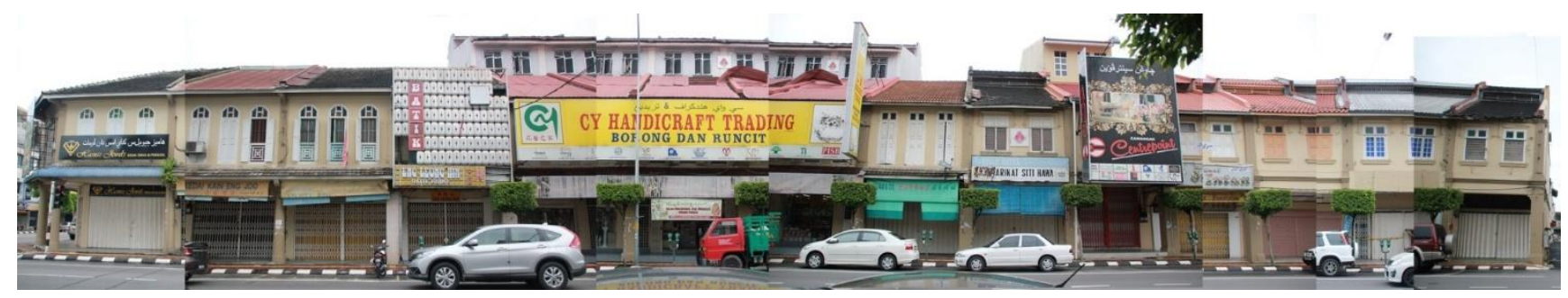

Figure 3: Shophouses along Jalan Temenggung in 2014

Interviews with local authority and shophouses' owner/tenants as respondents has been conducted to gain data and information regarding factors that influenced architectural intervention on shophouse facade in the study area. The Interview has been set up by an appointment through telephone to get data and information regarding the conservation guideline and development in the study area. The respondents for interview have been selected based on scope of research, regarding to development control in Kota Bharu, Kelantan. Majlis Perbandaran Kota Bharu, as the local authority of Kota Bharu is responsible in any 
development and construction approval in Kota Bharu, Kelantan. Shophouse owner/tenants or owners have been selected as one of the respondents as they are the significant parties who are responsible to the issues and factors of architectural interventions on shophouse façade.

\section{Literature Review}

Hülya. Y (2005) cited, the intervention within the built environment may occur at many levels (from preservation to redevelopment), at many scales (from individual building elements to entire sites), and will be characterized by one or more activities; ranging from maintenance to addition. With respect to interventions at an individual building scale, the scope of interventions are classified under few classification such as protection and maintenance, repair, replacement of existing features, replacement of missing features, alteration, completion of the missing part, new constructions behind the exterior retained façades, new additions to historic buildings, and destruction of ruined historic buildings which according to small scale interventions to large scale interventions (Hülya. Y, 2005)

Guan (2011) mentioned that shophouses comprise of a line of similar units construct alongside with existence of party walls making up one side of a street or city block, which eternally envisage as being merged to form a terrace. Demolition and alterations of heritage shophouses facade towards urban demand become one of the threats in conserving the existing historical building in Penang. As mentioned by Herzog, et.al (1982), historical building facades are preferred more over new ones. Hence, historical building facade plays an imperative role as they resemblance the identity and image of the district and placemaking. Destruction and insensitive alteration on original building façade are still happening, even though there were some conservation support struggling to conserve the heritage buildings (Wan Ismail et.al, 2005).

Rapid growth and urbanization in Malaysia particularly have put the heritage buildings in endangered situation, which might cause the demolition of historical value of the area. Mohamed,et. al (2008) pointed out that, rapid population growth, economic development and urbanization in developing countries with heritage significance being threatened. According to The Getty Conservation Institute (2009), due to fast urbanization and growth consequences of cities worldwide during last decade, urban heritage has confirmed to deteriorate. As added by Chun et.al (2005), there were conflict between urban change and heritage and this situation is physically obvious in all the towns and cities in Malaysia today.

Variations in way of life and contemporary urban setting due to urban needs and demand nowadays could not fulfilled their requirements, which conflicted with preservation issues (Hicran, 1994). Besides, Wan Ismail \& Shamsuddin (2005) asserted, uncontrolled growth of a city can influence the emergence of new modern buildings or facade in between the existing old buildings, which resulted the changing of urban fabric. Askari \& Dola (2009) pointed out that building façade, imposes significant influence on the identity of historical district, as it acts as a boundary between inner and outer space, where most of the matter of evaluation is by visitors of historical districts.

\section{Factors Influencing Architectural Interventions on Shophouse Façade in Kota Bharu Kelantan}

As far as globalization and urbanization taking place worldwide, the architectural evolution in Kelantan is not exempted and the preservation of any unique historical value should be done (Wan Ismail, 2005). Therefore, the construction of new buildings within historic districts or areas contains a significant number of historic buildings is often a difficult design problem. 
The demands of new construction and building programs often make it difficult for new building to fit in a sympathetic manner with the existing urban fabric (Sotoudeh \& Wan Abdullah, 2012). The quality of views and vistas of existing heritage buildings have been took for granted by their poor safeguarding and maintenance.

\section{Poor Awareness}

Lack of awareness and conservation effort by buildings users has led to the failure of sustaining the intrinsic heritage value of old buildings is one of the main factors that trigger the occurrence of architectural interventions on the heritage shophouses building in the study area. Indeed, poor maintenance and safeguarding by the buildings' owner has caused the unwanted view of deteriorate façade and dilapidated state of the building has trigger the demolition and major alteration works.

According to Samadi, et.al (2007), most of the owners or users of the shophouse failed to cooperate in conserving the façade, due to their problems as those who prefer the excess of their income in their daily dealings without realize the significance of heritage façade of the shophouse. For them, it is nothing more than a long legacy that need high repair costs which particularly as a burden for them in safeguarding the old shophouses (Samadi, et.al, 2007)

Poor of conservation awareness among the shophouse users has caused the new generation not to appreciate the city's remarkable history and past which should be preserved and remembered. Further, Raja Shahminan (2007) clarified design continuity between the old and new units have been ignored which make the new building seems to stand alone and alienated in their own environment. The lack of integration of development, particularly in design between the modern and the old building is defacing the historic identity of the area. Other factors that generate the emergence of architectural intervention is heritage buildings are being harmed because of demolition by the owner and destroyed the insistence of development and lack of concern for the community in an effort to preserve the heritage building, (Hamilton \& Zuraini 2002). The statement is granted by Karya (2007) where shophouse owners and tenants also pay an important role in conserving these elements, but they do not keep and maintain the buildings occupied by either assuming the building has no interest to further restored and maintained. As a result, the identity of a city is lost.

\section{Poor Enforcement and Restriction from Local Authority}

Enforcement by the local authority is also an important factor to overcome the unnecessary architectural intervention by means of major modification and renovation of heritage building form and facades. The delayed of enforcement implementation around 2006 have resulted in huge impacts to the old shophouses which have been totally renovated to modern building design which eventually demolish the significant original façade without considering the future consequences

Lack of effort by the government side to alert and educate the public on the value of the heritage buildings to the new generations is one of the factors contribute to the poor awareness of the society (Mohamed, et.al 2008). Moreover, the conservation enforcement by the authority only just started aggressively after 2006. A few years before 2006, alteration and renovation of the building façade and structure has been done illegally which demolish the original façade of the buildings. As a result, the shophouse façade has been modified and changed illegally by the owners before 2006 which has produced amount of modified shophouse façade because of there are no proper conservation guideline and enforcement by local authority. 
Furthermore, implementation of Control of |Rent (1966) previously which classified for prewar rented properties was intended to avoid the removal of tenant without tearing down the buildings and also to guarantee the tenants of controlling the rent amount. However, after the act was amended to Control Act (repeal) Act 1997 (act 572), the increasing of rent by the building owner has forced the tenant to move out as they could not afford to pay the higher rent. Consequently, numerous shophouses were left vacant and abandoned with dilapidated state which affects the urban context of heritage buildings.

\section{Modification of Building Function}

Changes in lifestyle toward modernization has influence the design of the buildings according to urban needs and construction, which is inappropriate to their current users. Hence, a variety of interventions have been recognized in order to adapt the buildings into current situations and needs. Yaakob et.al (2012) appointed that, urban evolution and town distribution in Malaya was primarily a consequence of the British intervention in mainland Malaya around the 1850s.

The existence of unnecessary construction and renovation on the shophouse buildings create an issue to the society. The conversion of shophouse unit into bird's nest has affected the main function of the shophouse for living and commercial purposes, which creates poor view and unhygienic neighborhood environment that distracts the visual and air quality. The enforcement and action taken by the local authority is questionable, as a lot of report and complaints have been made but there is no strict action taken. In fact, they are willing to pay high amount of fees and summons for the sake of continuing the activity as it is worth their income. Thus, the activities remain and still continue regardless of the neighborhood complaints.

\section{Urbanization}

High demand of urban lifestyle and needs nowadays has encouraged the owners to convert the old façade of the shophouse to a modern and practical building feature. Besides, conservation works require high skill workers and cost to sustain the originality of the façade and ambiance. Further, natural causes and weather condition are inevitable which cause the building to deteriorate with fungus and time factors. Buildings with poor and dilapidated condition tend to be demolished rather than preserved in order to save construction cost.

Besides that, architectural interventions which involve control modifications and alteration with responsive and modest way applying the specific technique by using suitable material to sustain the originality elements of the façade. Further, architectural interventions by means of revitalization of physical façade are essential in improving the old façade from deterioration as well as preserving the ambiance of heritage realm. Thus, architectural interventions which comprised of restoration and repair with control and guideline implementation shall develop and preserve the originality of the building façade and sustain the existing heritage environment.

\section{Mother Nature}

As said by Burke (2011), building form and image will be changed physically due to deterioration by means of weather and time factor which could affects the occupants' way of living and habitat. Thus, the deteriorated and damaged buildings can be improvise through restoration and continuous maintenance by the owner in order to sustain and preserve their properties (Burke, 2011). Deteriorated and decayed building regarding to natural causes and time factor has created poor visual and physical view of the heritage area. Those old shophouses were left in dilapidated state without any refurbishment and restoration work which form 
unhealthy and inappropriate surrounding for commercial activities, which eventually 'kill' the public realm. Also, the used of oversized and massive billboard in front of the shophouse façade which totally blocked the façade elements has created inharmonious façade by hiding the original feature of the heritage buildings.

\section{Finding Analysis}

Two groups of respondents for survey method have been selected, which are local authority and owner or users of the shophouse buildings. The survey with both local authority, Majlis Perbandaran Kota Bharu (MPKB) and shophouse owners will explain the architecture interventions and conservation issues as well as the implementation of development control and conservation guideline in the study area. The survey is intended to unfold the factors influencing the architectural interventions and their effects on shophouse façade as well as their opinion and suggestion to overcome the issues and improve the conservation

\section{Shophouse Owner}

From the survey, the owners of the shophouses who inherited the shophouse from the ancestor mentioned that, the earliest shophouse building was built around 1920's where the origin owners of the buildings were mostly Indian merchant who left and moved out after a few decades and were taken over by Chinese merchants. According to the owner, most of them were aware and knowledgeable of development and conservation guideline stressed by the local authority. The shophouse are allowed to be renovated based on particular rules and constraints, such as the front facades of the buildings should strictly maintain the original elements, while the back or rear façade of the building can be renovated.

Unfortunately, some of the shophouses' users have ignored the restriction, where the front façade has been renovated and modified to a new modern façade irrespective the original existing urban fabric. Paying certain amount of money to the local authority for their illegal renovation is the best option for the owner, as that would be more beneficial for their business. From the survey, although most of them were aware of the restriction in development guideline of local authority, the passion for conservation is still not their priority compared to their income. Apart from that, the ignorance of heritage value has led them to change the original facades and building structure to fulfill their urban needs and income. It is the most beneficial way for them to develop their business, instead of using huge amount of money for conservation work which requires high costing than new construction. In addition, total modification of entire façade without emphasizing on the features and benefits of the original building by converting old façade of straits eclectic architecture style to new modern architecture style that triggered by urban lifestyle which required new modern and practical building feature to fulfill their necessities. Indeed, conservation and refurbishment work require an expertise to offer inclusive conservation works, which required high construction cost compared to demolition work. Based on the site survey and observation, there were a few of the shophouse units were converted from commercial uses to illegally build swiftlet nest above the shophouse unit. Although there were restrictions from the local authority, the emergence of sparrow nest still continues which subsequently interrupts the hygiene quality and ambiance of the surrounding.

According to the shophouses' user, many complaints and reports have been made to the local authority; regrettably there were no action to overcome the problem. Instead, it was informed that the owner of the sparrow nest were also willing to pay high amount of money for the sake of continuing the illegal activity, as the business have gave them a sizable income. Hence, there was an agreement between the owners and local authority, that they must have a yearly license 
for the bird's nest activity for at least RM1000 for 1 storey of birds' nest accommodation. As a result, the activity still continues even though it is not compliance to the existing building ambiance regardless the neighbourhood needs and sensitivity.

After the abolishment of Rent Control Act to Control Act (Repeal) Act 1997 (Act 472), many of shophouses users cannot afford to pay the increasing rent and decided to be moved out and left the buildings. In fact, some of the shophouse were burnt and left abandoned and in a dilapidated state which creating poor surrounding view. Thus, the significance of heritage value ambiance slowly disappeared by time.

\section{Local Authority}

According to Chief Assistant Director Town Planning Kota Bharu, there are a few issues raised to implement conservation and preservation of building façade in gazzetted heritage zone in Kota Bharu, Kelantan, which trigger the demolition and ignorance of heritage value of that area. Lacking of financial sources and limited budget from government are one of the main factors in sustaining the heritage building, which require an investment to purchase particular materials to ensure the originality image of the façade. Budget constraint has cause the poor implementation of building conservation in Kota Bharu, Kelantan. Thus, the refurbishment works towards any abandoned shophouses are very limited due to financial limitation.

Conservation and refurbishment of building façade require high skill workers in order to preserve the existing intrinsic façade treatment as well as sustaining the heritage value of the façade. Lack of expertise and skill workers service in this state produce low quality refurbishment work and create low value of heritage façade. Thus, the substantial heritage value is not worthy and appreciated by the owner. Conservation enforcement by the authority only just started aggressively after 2006, which alteration and renovation of the building façade and structure has been done illegally which demolished the original façade of the buildings has started before 2006. There were no action or penalty taken by MPKB towards the shophouse owners that went through architectural interventions before the aggressive enforcement implementation.

However, illegal renovation on shophouse façade still continue towards 2014 such as changes of windows elements, additional upper floor level, changes of roof material and others. According to MPKB, warning notice has been given to the owner towards their renovation works. In fact, some of the owners were forced to stop all the constructions work immediately if it is not according to development guideline. Shophouse owner have to apply for a license and to be approved by local authority to run their business. Unfortunately, according to observation in 2014 the architectural interventions on shophouse façade still exist in the study area.

The construction party consists of architect, developer and contractor also play an essential role to ensure the sustainability of heritage façade of the heritage zone. The disputation of architecture drawing plan that have been submitted to the authority are not according to actual construction have cause the modification of original heritage façade to the new façade which distracted the heritage value of the façade. Awareness and initiative from the community itself has also influenced the effectiveness of conservation work, as majority of them never care about the value of the building for their economic purposes. 
From the survey, architectural interventions on shophouse façade elements by means of any changes or renovation must be in accordance to the development control guideline by local authority, MPKB. Otherwise, the development or any renovation works are prohibited.

\section{References}

Ahmad, A. G. (2008). Heritage Conservation Retrieved March 2013, 23 from http://www.hbp.usm.my/conservation/

Askari, A.H. \& Dola. K. (2009), Influence of Building Façade Visual Elements on Its Historical Image: Case of Kuala Lumpur City, Malaysia, Journal of Design and Built Environment, Vol. 5, December 2009, pp. 49-59

Burke, T. (2011), Building Adaptation and Conservation, University of Westminster Open Resources For Built Environment Education Retrieved November 21, 2013 from: http://www.orbee.org/images/5cc-resource- files/

Chun, H. K, Hasan. A. S \& Noordin. N. (2005), An Influence Of Colonial Architecture To Building Styles And Motifs In Colonial Cities In Malaysia, 8 th International Conference Of The Asian Planning Schools Association 11-14th September 2005

Guan, T. C. (2011), Learning From The Singapore Shophouse: Towards A Sustainable Tropical Architecture

Hamilton, B. \& Zuraini M. A. (2002). BS role in conservation works. 2nd. National Conference on Building Control, 22-23hb. Januari 2002, Selangor. Hilton Hotel Petaling Jaya

Herzog, T. R., Kaplan, S., \& Kaplan, R. (1982), The Prediction of Preference for Unfamiliar Urban Places, Journal of Population and Environment, 5(1): 43-59

Hicran, T. (2006), Change with/versus Conservation: Architectural Interventions and Their Effects on the Character of the Historic Urban Patterns: A Case Study on Historic Urban Site of Izmit, Turkey

Hülya, Y. (2005), An Evaluation Of Interventions In Architectural Conservation: New Exterior Additions To Historic Buildings,İzmir Institute of Technology.

Karya, R. (2007), Kajian Fasad Bangunan Rumah Kedai Di Bandar Kangar Sebagai Satu Pendekatan Pemuliharaan Bangunan, Retrieved March 23, 2014 from http://www.polimas.edu.my/web4/images/inovasi/pg\%2069\%20Ruslinda\%20(fasad\% 20bangunan).pdf

Mohamed.B, Ahmad.A \& Badarulzaman. N (2008), Challenges of Historic Cities in the New Millennium: Lessons from Malaysia.

Mohga, E. Embaby (2014), Heritage conservation and architectural education: "An educational methodology for design studios", Retrieved December 28, 2015 from: http://www.sciencedirect.com/science/article/pii/S1687404814000030

Raja Shahminan, R.N. (2007), Kajian Tipologi Rumah Kedai Awal Era Belanda Di Bandar Melaka: Sumbangan Kepada Bidang Pemuliharaan Di Malaysia

Samadi, Z., Mahmud-Shahril A., Masri. M., (2007), Pemuliharaan Warisan Senibina Rumah Kedai Bagi Kemakmuran Bandar: Isu Dan Cabaran, Prosiding Seminar Kebangsaan Rupa Bandar Malaysia: Mengekal Warisan Membina Identiti, 28-29 November 2007, Lumut, Perak. 384-394

Sotoudeh, H. \& Wan Abdullah. W.M.Z., (2012), Affected Variables on Successful Infill Design in Urban Historic Context, School of Built Environment, UTM University, Malaysia Poscode 31810, Skudai, Johor, Malaysia

The Getty Conservation Institute (2009), Historic Urban Environment Conservation Challenges and Priorities for Action Experts Meeting, March 12-14, 2009 Retrieved from: http://www.getty.edu/conservation/our_projects/field_projects/historic/experts_mt_ mar09.pdf 
Wan Ismail, W.H. \& Shamsuddin. S., (2005), The Old Shophouses As Part Of Malaysian. Urban Heritage: The Current Dilemma, 8 th International Conference Of The Asian Planning Schools Association 11-14th September 2005

Yaakob, U., Masron. T. \& Fujimaki. M., (2012) Ninety Years of Urbanization in Malaysia: A Geographical Investigation of Its Trends and Characteristics, Ritsumeikan Journal of Social Sciences and Humanities 